\title{
A 3D-printed innovative pedal fixator for connecting different pedal-operated tools to improve work ergonomics during advanced diagnostic and therapeutic endoscopic procedures
}

Recent techniques in diagnostic and therapeutic endoscopy require the use of different foot-controlled devices. For example, water immersion colonoscopy [1] and underwater endoscopic mucosal resection (EMR) [2] require the parallel use of two foot pedals, one to control the electrosurgical unit and the other to control the peristaltic pump to fill the colon with water. For endoscopic submucosal dissection [3], the problem becomes even more complex with three pedals to be managed in parallel, since the pump that activates the knife injection must be added.

Although quite difficult to measure, the lack of connection between the various pedals of different shapes and brands leads most teams to place them on the floor without affixing them, leading to numerous displacements of these devices during the procedure, forcing the operator to look away from the operating field to reposition his or her feet. These wanderings to find the pedal are a source of lost time, additional stress and, for beginners, a change of position that forces them to reposition themselves with the scope. This can be a problem when controlling a bleed, for example, where holding a fixed position in front of the bleed is important.

To reduce these difficulties, we have designed and 3D-printed an innovative and versatile device allowing an operator to connect the electric generator and peristaltic pump pedals whatever their shape and brand ( $>$ Video 1, > Fig. 1). This device was designed to be versatile, allowing an operator to choose the distance between the pedals, the angulation as well as the position (right/left). Anti-slip systems prevent it from moving. We present here the case of a colonic dissection for a laterally spreading tumor with and without the IPEFIX pedal device (Innovative Pedal Fixator, Lab 3D HCL, Hospices Civils de Lyon).

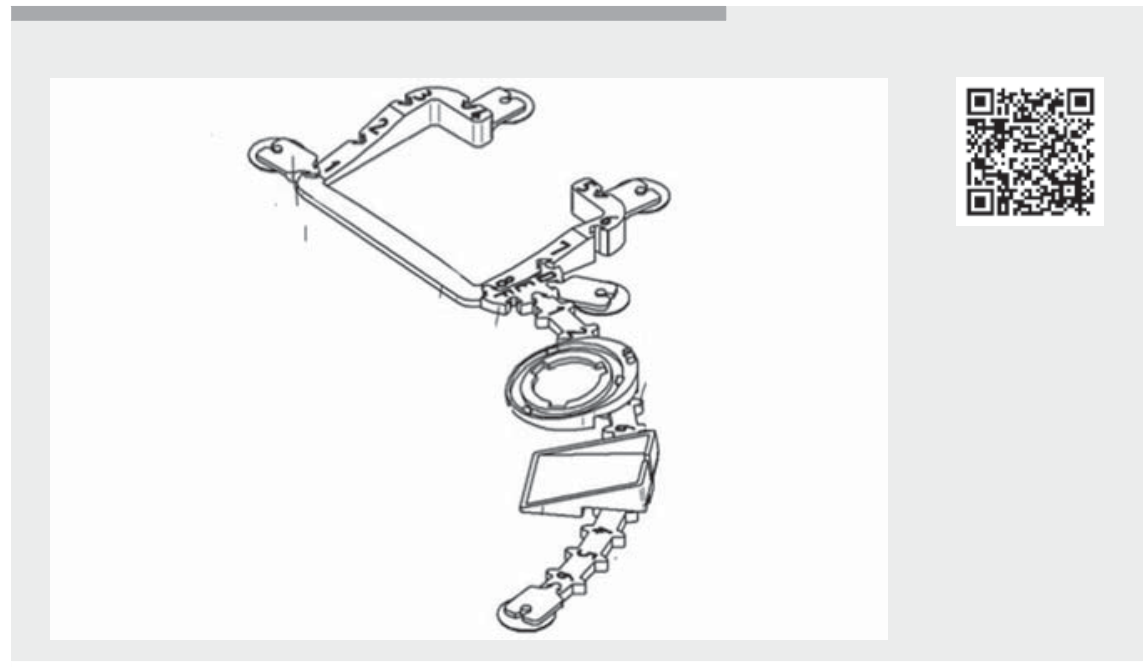

$\checkmark$ Video 1 Parallel between foot movement and endoscopic view of the procedure with and without the innovative pedal fixator (IPEFIX) device.

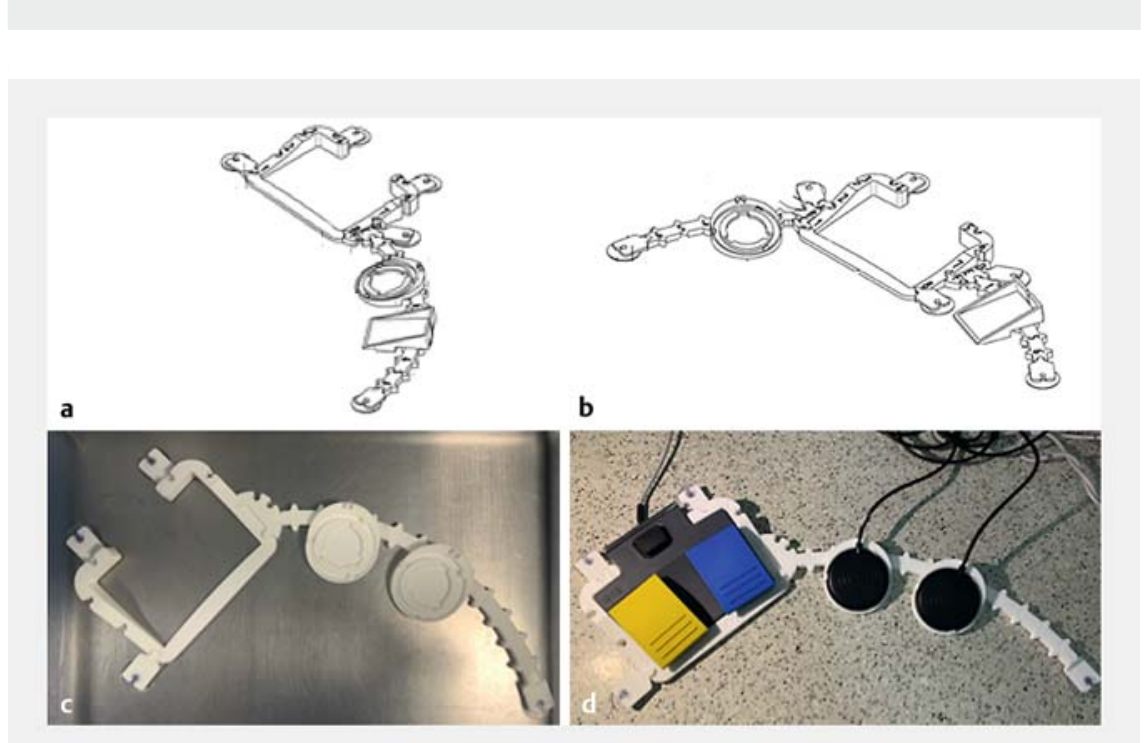

Fig. 1 Innovative pedal fixator (IPEFIX) device in schematic and real views.

Future clinical studies are needed to measure the clinical impact of such a device.

Endoscopy_UCTN_Code_TTT_1AU_2AZ

\section{Competing interests}

The authors declare that they have no conflict of interest. 
Clara Yzet ${ }^{1}$, Jérôme Rivory ${ }^{1}$, Mikael Mochet ${ }^{1}$, Mélia Virely ${ }^{2}$, Peggy Leplat-Bonnevialle ${ }^{2}$, Jérémie Jacques ${ }^{3}$, Mathieu Pioche ${ }^{1}$

1 Endoscopy and Gastroenterology Unit, Edouard Herriot Hospital, Hospices Civils de Lyon, Lyon, France

2 Co'Lab3D HCL, Hospices Civils de Lyon, Lyon, France

3 Gastroenterology and Endoscopy Unit, Dupuytren University Hospital, Limoges, France

\section{Corresponding author}

\section{Mathieu Pioche, MD}

Endoscopy Unit, Department of Digestive Diseases, Pavillon L - Edouard Herriot Hospital, 69437 Lyon Cedex, France mathieu.pioche@chu-lyon.fr
[1] Lesne A, Rouquette O, Touzet S et al. Adenoma detection with blue-water infusion colonoscopy: a randomized trial. Endoscopy 2017; 49: 765-775. doi:10.1055/s-0043105073

[2] Yamashina T, Uedo N, Akasaka T et al. Comparison of underwater vs conventional endoscopic mucosal resection of intermediate-size colorectal polyps. Gastroenterology 2019; 157: 451-461.e2. doi:10.1053/j.gastro.2019.04.005

[3] Bordillon P, Pioche M, Wallenhorst T et al. Double-clip traction for colonic endoscopic submucosal dissection: a multicenter study of 599 consecutive cases (with video). Gastrointest Endosc 2021; 94: 333-343. doi:10.1016/j.gie.2021.01.036

Bibliography

Endoscopy 2022; 54: E650-E651

DOI 10.1055/a-1732-7477

ISSN 0013-726X

published online 4.2 .2022

(c) 2022. Thieme. All rights reserved.

Georg Thieme Verlag KG, Rüdigerstraße 14,

70469 Stuttgart, Germany
ENDOSCOPY E-VIDEOS

https://eref.thieme.de/e-videos

口回 Endoscopy E-Videos is an open access online section, 回: reporting on interesting cases and new techniques in gastroenterological endoscopy. All papers include a high quality video and all contributions are freely accessible online. Processing charges apply (currently EUR 375), discounts and wavers acc. to HINARI are available.

This section has its own submission website at

https://mc.manuscriptcentral.com/e-videos 